\title{
Description of Thioploca ingrica sp. nov., nom. rev.
}

\author{
S. MAIER \\ Department of Zoological and Biomedical Sciences, Ohio University, Athens, Ohio 45701
}

\begin{abstract}
Although Thioploca ingrica has not been isolated in pure culture and was omitted from the Approved Lists of Bacterial Names, the distinctive gross morphology of this species makes definitive identification possible through microscopic examination. The morphological description given here provides the type description (Rule 18a) and revives the name Thioploca ingrica sp. nov.; this organism was originally named and recognizably described by Visloukh in 1911.
\end{abstract}

The genus Thioploca was discovered in freshwater sediments by Lauterborn (1), who described Thioploca schmid$l e i$, which became the type species of this genus. Of the four species listed in Bergey's Manual of Determinative Bacteriology, 8th ed. (2), only the type species was included on the Approved Lists of Bacterial Names (7), presumably because of lack of pure cultures and paucity of information about the other species; however, the same is also true for the type species, which was retained. Yet, we know more about one of the excluded species, Thioploca ingrica, which was originally described by Visloukh in 1911 (8), than about the included type species. The gross morphology of members of the genus Thioploca is so distinct that definitive identification can be made by microscopic examination.

$T$. ingrica was recovered from grab samples of sediments from Lake Constance (near Staad), a spring in Lower Saxony, Germany (5), and western Lake Erie (4). The flocs of this colonial form are recognizable and can be picked up with a Pasteur pipette when a thin slurry of the sediment surface layer is rocked back and forth in a large flatbottomed dish. The organism can be maintained in the laboratory in undisturbed sediment samples kept in large jars and overlaid with tap water at 8 to $20^{\circ} \mathrm{C}$. At approximately yearly intervals a few stems of extracted (6) grass are stuck vertically into the sediment. Since $T$. ingrica colonizes these stems in time, extraction of a stem provides a harvesting procedure which results in minor disturbance of the stratification of the sediment.

Washed flocs were examined in wet mounts and photographed through a microscope. The gross morphology and fine structure of the Lake Erie strain have been reported previously (4), as has the gross morphology of the strain from Lower Saxony (5). Figures 1 and 2 show $T$. ingrica from Lake Constance. A modification of the Beggiatoa enrichment (6) has provided mixed laboratory cultures of $T$. ingrica from Lake Erie (3). However, pure cultures have never been obtained. In all instances, the trichome diameters from a culture or from a natural sample have fluctuated only within narrow limits, and this provides an effective basis for recognition.

Observations with mixed cultures (3) have revealed that $T$. ingrica requires lower concentrations of hydrogen sulfide and oxygen than Beggiatoa strains. In addition, $T$. ingrica is more sensitive to fluctuations in the concentrations of these gases. Indeed, changes in the relative concentrations of these gases result in the emigration of trichomes from their sheaths and relocation in a sediment horizon of suitable conditions where the colonial, sheathed habit is re-established. The organism is definitely microaerophilic.

Recognizing the ease with which confident identification by microscopic examination is achieved based on gross morphology, I give the morphological description below.

Thioploca ingrica sp. nov., nom. rev. (Thi.o.plo'ca. Gr. neut. n. thion sulfur; Gr. fem. n. ploke a braid, a twist; M.L. fem. n. Thioploca a sulfur braid; in'gri.ca. M.L. adj. ingrica pertaining to Ingria, ancient district of Leningrad, Russia.) Flexible trichomes made up of numerous cells, generally with numerous sulfur inclusions, occur in parallel or braided fascicles, which are enclosed by a common sheath of variable width. The number of trichomes within a sheath is variable. The sheath is frequently encrusted with detritus. Individual trichomes show independent gliding movement, and they may emerge from the ends of sheaths or from breaks in a sheath. The long trichomes are of uniform diameter, and their terminal segments are often tapered. Trichome diameters are 2.0 to $4.5 \mu \mathrm{m}$. Cell length, exclusive of the terminal cell, varies from 1.5 to $8.0 \mu \mathrm{m}$. Microaerophilic. Identified from sediments of fresh and brackish waters of various localities in Central Europe and Lake Erie. Not isolated in pure culture.

A description of nutritional and physiological characteristics must await procurement of pure cultures.

Differentiation between $T$. schmidlei and $T$. ingrica is based exclusively on trichome diameters, which are 5.0 to 9.0 and 2.0 to $4.5 \mu \mathrm{m}$, respectively.

Characteristics which qualify $\boldsymbol{T}$. ingrica for inclusion in the genus Thioploca. The following characteristics qualify $T$. ingrica for inclusion in the genus Thioploca: flexible, uniseriate, multicellular, independently gliding trichomes with sulfur inclusions, enclosed by a common sheath: uniform diameter of trichomes except for terminal segments; found in the upper layers of sediments.

Characteristics essential for membership in the species $T$. ingrica. The following characteristics are essential for membership in the species $T$. ingrica: trichome diameter, 2.0 to $4.5 \mu \mathrm{m}$; isolated from sediments of fresh and brackish waters.

Diagnostic characteristics. The following characteristics are diagnostic: uniform trichome diameter of 2.0 to $4.5 \mu \mathrm{m}$; common sheath; sulfur inclusions; independent gliding movement; lack of obvious pigments; isolated from fresh or brackish water sediments.

Re-examination of locations in Lake Constance was made possible through the hospitality of W. Reichardt and the Institute of Limnology, University of Freiburg.

\section{LITERATURE CITED}

1. Lauterborn, R. 1907. Eine neue Gattung der Schwefelbakterien (Thioploca schmidlei nov. gen. nov. spec.). Ber. Dtsch. Bot. Ges. 25:238-242. 


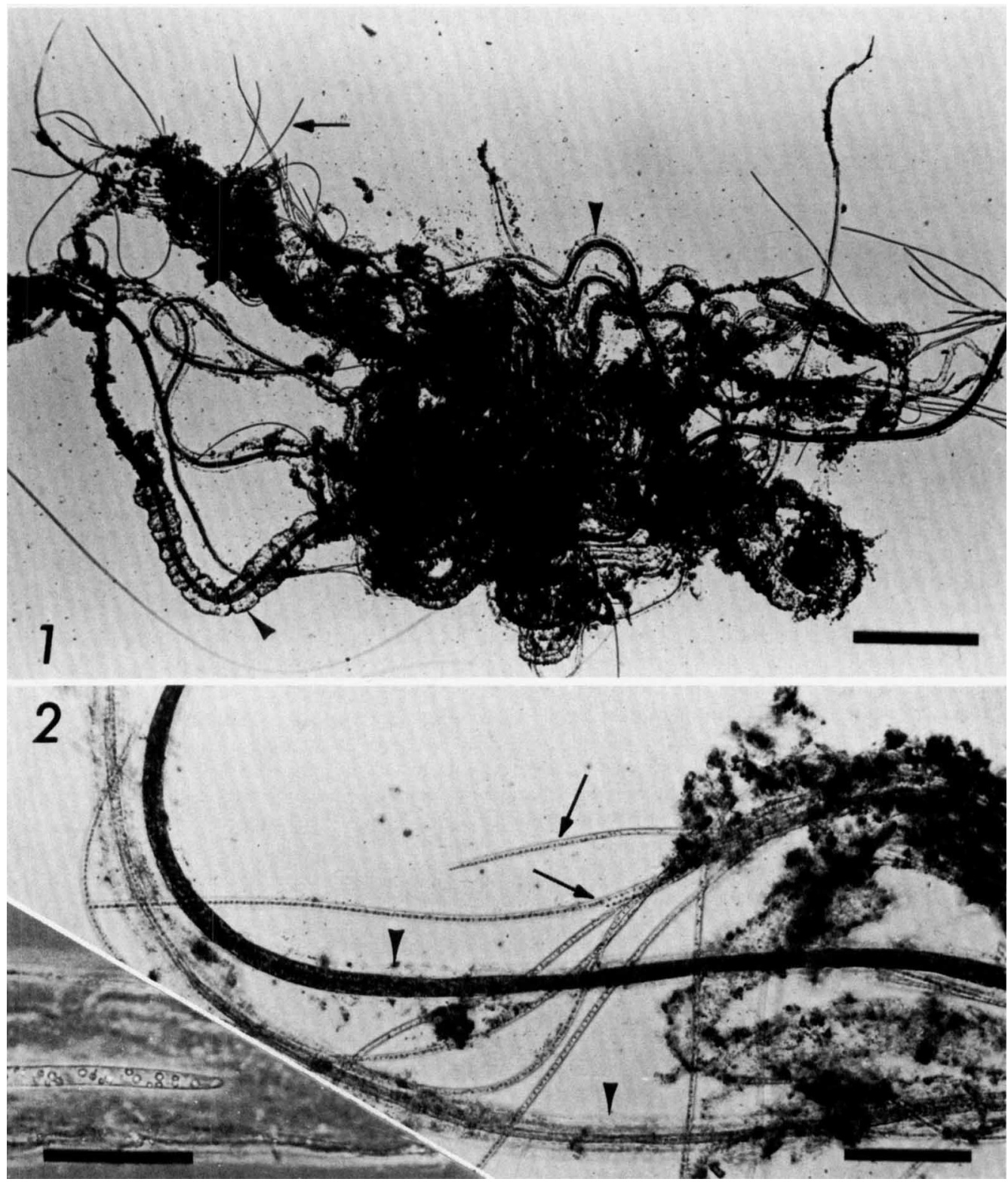

FIG. 1. Floc of tangled sheathed fascicles of trichomes (arrowheads) of $T$. ingrica washed from the sediment of Lake Constance near Staad. Some trichomes (arrow) are gliding out of their sheaths. Bright-field microscopy. Bar $=200 \mu \mathrm{m}$.

FIG. 2. Portion of floc of sheathed fascicles of trichomes (arrowheads) of $T$. ingrica (Lake Constance), some of which (arrows) are gliding out of their sheath. Bright-field microscopy. Bar $=50 \mu \mathrm{m}$. (Inset) Tapered terminal portion of a single sheathed trichome with sulfur inclusions. Phase-contrast microscopy. $\mathrm{Bar}=25 \mu \mathrm{m}$.

2. Maier, S. 1974. Genus III. Thioploca Lauterborn, p. 115-116. In R. E. Buchanan and N. E. Gibbons (ed.), Bergey's manual of determinative bacteriology, 8th ed. The Williams \& Wilkins Co., Baltimore.

3. Maier, S. 1980. Growth of Thioploca ingrica in a mixed culture system. Ohio J. Sci. 80:30-32.

4. Maier, S., and R. G. E. Murray. 1965. The fine structure of Thioploca ingrica and a comparison with Beggiatoa. Can. J. Microbiol. 11:645-655.

5. Maier, S., and W. C. Preissner. 1979. Occurrence of Thioploca in
Lake Constance and Lower Saxony, Germany. Microb. Ecol. 5:117-119.

6. Scotten, H. L., and J. L. Stokes. 1962. Isolation and properties of Beggiatoa. Arch. Mikrobiol. 42:353-368.

7. Skerman, V. B. D., V. McGowan, and P. H. A. Sneath (ed.). 1980. Approved lists of bacterial names. Int. J. Syst. Bacteriol. 30:225420.

8. Visloukh, S. M. 1911. A new sulfur-microorganism from the Neva, Thioploca ingrica Visl. Russ. Vrach 10:2102-2104. (Translated from Russian.) 